\title{
Vertical and horizontal trust and team learning: the role of organizational climate
}

\author{
Adebayo Agbejule \\ Department of Mechanical and Production Engineering, \\ Vaasa University of Applied Sciences, Vaasa, Finland \\ Jukka Rapo \\ Wärtsilä Finland $O y$, Vaasa, Finland, and \\ Lotta Saarikoski \\ Department of Mechanical and Production Engineering \\ Vaasa University of Applied Sciences, Vaasa, Finland
}

\begin{abstract}
Purpose - This study examines the relationship between trust, organizational climate and team learning among project team members (PTM). In recent years, many companies have come to recognize the important role team learning plays in achieving competitive advantage.

Design/methodology/approach - Data were collected through a survey questionnaire, and responses from 86 PTM provide support for the research model and demonstrate that how organizational climate mediates the relationship between trust and team learning.

Findings - The structural equation analysis of the data collected from 86 project team members indicate that both vertical and horizontal trust influences organizational climate, which, in turn, is a determinant of team learning. In addition, although both types of trust contributed to organizational climate, the results indicated that horizontal trust had a greater influence on organizational climate and team learning.

Research limitations/implications - The study employed the survey method and is not without limitations. The first limitation concerns our sample size, which was selected from one global company. Second, the survey data were all collected at a single point in time. Therefore, the authors cannot unambiguously infer causality. To attempt to do so, it would be useful to investigate the model in the context of organizational and development change. Despite these limitations, the results of the study have implications for theory and practice.

Practical implications - The implication for theory is that the results provide empirical support for the view that organization climates mediate the relationship between trust and team learning. On the practical side, the organizations should also pay more attention to increasing trust at the work place, especially among PTM that may contribute to favorable organizational climate, which is vital for team learning.

Originality/value - This paper addresses the simultaneous role of vertical and horizontal trust on organizational climate and how it contributes to team learning. The results indicate that organizations emphasis on horizontal trust can plays a vital role in team learning, which is a contribution to enhancing teamwork and performance in organizations.
\end{abstract}

Keywords Vertical trust, Horizontal trust, Organizational climate, Team learning

Paper type Research paper

\section{Introduction}

The role of project management appears strongly in modern world businesses and it is recognized as an obligatory element of many companies in the global competitive

(C) Adebayo Agbejule, Jukka Rapo and Lotta Saarikoski. Published by Emerald Publishing Limited. This article is published under the Creative Commons Attribution (CC BY 4.0) licence. Anyone may reproduce, distribute, translate and create derivative works of this article (for both commercial and noncommercial purposes), subject to full attribution to the original publication and authors. The full terms of this licence may be seen at http://creativecommons.org/licences/by/4.0/legalcode

The authors would like to thank the anonymous reviewers for their constructive comments.

The role of organizational climate 
IJMPB 14,7 environment. By following the set of project management processes, the company can serve the customer needs more effectively and in that way improve, for example, customer satisfaction (PMBOK, 2013). As a result, project management requires multiple skills to lead the project team and maintain a climate of trust in the project environment since the team members are most important assets and are those who deliver effort toward set targets and achievements, not just the application of methods and tools. Although the importance of team learning has known to enhance innovation and promote project success and organizational performance (e.g. Birkinshaw and Mol, 2006), research on factors that facilitate team learning in project-based organizations is still evolving.

Research has pointed out several conditions that influence team learning (Schneider et al., 2000; Lin, 2007; Kozlowski and Bell, 2008; Brodbeck et al., 2010; Ramirez et al., 2014) with organizational climate being an important vital component. In this context, it is important to mention the role played by trust as a key construct that is beneficial for promoting organizational climate. Trust is in this case important because it enables individuals to develop shared perceptions, expectations and behavioral normal with their supervisors and team coworkers which encourages favorable organizational climate (Dirks and Ferrin, 2001; Costa and Anderson, 2011). One of the key challenges facing project managers is to create a strong project team with appropriate knowledge and skills to achieve project success in a favorable organizational climate. In a project context, people must work and learn together as a team. Teamwork can only be achieved with support from informal processes of interaction among team members (Wang, 2001). Edmondson (1999) emphasizes the importance of interpersonal exchanges in project team that promotes team learning. According to Savelsbergh et al. (2015), continuous learning in both project content and interpersonal dynamics is a key driver for projects teams to remain adaptive and flexible in the global competitive environment. With the present study, our focus is on the antecedents of team learning that may be influenced by trust and organizational climate. Team members need shared norms and values supported by favorable organizational climate to develop healthy team processes, such as learning, communication and coordination (Edmondson et al., 2007). There is available empirical evidence suggesting that a favorable organizational climate of free-flowing information, trust among subordinates and trust between superiors and subordinates play a critical role in enhancing team learning (e.g. Hinds and Pfeffer, 2003; Wasko and Faraj, 2000; Wang and Tarn, 2018). However, the simultaneous role of vertical and horizontal trust and their relationship with organizational climate remains largely unexplored in project settings.

The objective of this research is twofold. Consistent with previous research (e.g. Winter et al., 2006; Soderlund et al., 2008; Savelsbergh et al., 2015), this study examines the antecedents of team learning in project management environment and intends to fulfill existing gap in this area. First, although trust has been acknowledged as a critical role in team behavior (e.g. Schaubrock et al., 2011; Buvik and Tvedt, 2017), little has been done in investigating the role of trust on team learning. Team learning is more likely to take place in a favorable climate where team members trust each other. A favorable climate encourages team members to interact, share information and promote each other's learning (Chen and Huang, 2007). Second, the study will contribute to the trust literature in the field of project management. Researchers (e.g. Ozyilmaz, 2010) have called for the need to explore simultaneously both vertical and horizontal trust as employees may relate to supervisors and coworkers in different ways that can affect their behavior in an organizational setting. To address this gap, we address the following research questions: what is the role of trust in promoting team learning? Does organizational climate play a role in the relationship between trust and team learning? Especially, we are interested to know how vertical and horizontal trust promotes a favorable organizational climate that enhances team learning from the group behavior perspective. Research on group behavior highlights interpersonal climate and group processes and are underpinned by organizational research on team effectiveness. Previous researchers have focused on the 
importance of trust in project success (e.g. Henderson et al., 2016; Pinto et al., 2009; Smyth et al., 2010). However, the linkage to organizational climate and how it can contribute to team learning is largely unexplored. Trust is a foundation of team learning. Interpersonal trust among superiors and subordinates facilitates cooperation and creates a favorable climate for team learning. Project team members are likely to take risks and freely suggest and share new ideas when they can trust others (e.g. Ekvall, 1996; Schaubrock et al., 2011). To the best of our knowledge, this study is the first to investigate how both vertical and horizontal trust affects organizational climate and how they influence team learning. In this study, we investigate the mediating effects of organizational climate on the relationship between trust (vertical and horizontal) and team learning.

The remainder of the paper is structured as follows. The next two sections define the constructs and develop the theoretical model ending with testable hypotheses. This is followed by the results and discussions. The section identifies the limitations of the study and provides some directions for further study.

\section{Theoretical development and hypothesis}

Most of the research on team effectiveness has been driven by the input-process-output (IPO) model (see Ilgen et al., 2005). Our theoretical development is based on team effectiveness model proposed by Kozlowski and Ilgen (2006). They proposed three aspects of a team processes-composition, training and leadership that shape team processes and team learning. Team processes are "members' interdependent acts that convert inputs to outcomes through cognitive, verbal, and behavioral activities directed toward organizing taskwork to achieve collective goals" (Marks et al., 2001, p. 357). Team learning is influenced by organizational context, group structure and group process. Previous researchers studied cognitive team processes (e.g. psychological safety, Edmondson, 1999, sub-group strength, Gibson and Vermueulen, 2003), cooperation, Tjosvold et al. (2003), task interdependence, Widman and Mulder (2018) and team climate, Schneider and Barbera (2013); motivational team processesteam cohesion (e.g. Imam and Zaheer, 2021), team efficacy (Huang et al., 2017) and team conflict (Van der Haar et al., 2017) and team behavioral process (e.g. team self-regulation, Gevers et al., 2009) to understand the predictors of team learning. Although researchers have suggested the importance of trust (Chiocchio et al., 2011; Wang and Tarn, 2018) and organizational climate (e.g. Ekvall, 1996; Chen and Huang, 2007), little has been done in investigating how both the roles of horizontal and vertical trust, and organizational climate influence team learning. Trust is the foundation that enables people to work together, and it is an enabler for social interactions to create a favorable organizational climate (Nemiro et al., 2008). When project team members trust each other, can freely suggest ideas, collect information and interact with colleagues and superiors, which are critical for team learning. Trust makes it possible to share even negative aspects and criticism more openly (Barnett et al., 2010) and plays an essential role in creating a favorable climate for information exchange and ideas generation in enhancing team learning. Organizational climate has an impact on team processes, and it can be explained in an organizational context as a mediator between resources and outcomes, such as team learning (Ekvall, 1996; Porzse et al., 2012). Accordingly, we study the mediating role of organizational climate between trust and team learning.

\subsection{Trust}

Research in organizational behavior suggests that trust is highly beneficial for organizations (Dirks and Ferrin, 2001, 2002). For example, Dirks and Ferrin found that trust in organizations have been related with job satisfaction and organizational commitment. Lewicki et al. (2006) and Colquit et al. (2007) have also suggested that trust contributes to 
IJMPB

14,7

favorable organizational citizenship behavior and improve performance. Tan and Lim (2009) define trust as "an employeés willingness to be vulnerable to the actions of the organization, whose behavior and actions he or she cannot control". Tyler (2003) suggests that trust is important because it is a strong desire to understand how to create effective cooperation within organizations and how trust enables cooperation. According to Barker and Camarata (1998) trust is cognitive and based on past experiences/expectations. Trust is also broad and encompasses varied approaches, which most commonly focus on psychological phenomenon (Clark and Payne, 1997). In addition, trust is not a simple "either/or" matter or "conditional" and "unconditional" or "strong" and "weak" (Dietz and Hatog, 2006). Trust promotes openness and encourages internal motivation that facilitates cooperation in organizations. Trust also encourages transparency that provides a number of outcomes such as creating a favorable organizational climate that are beneficial for relationship team such as projectbased organization (Jahansoozi, 2006).

In this study, we focus on Tam and Lim's (2009) proposal of organizational trust, who suggested that organizational trust can be viewed at two levels: trust between coworkers (horizontal trust) and trust in supervisors (vertical trust). Vertical trust is the degree to which employees trust actions of their superiors or the organizations where they work, and horizontal trust is the degree to which employees trust the people they work with, trust what they do and enjoy being with them. Trust as variable in the relationship between supervisor and subordinate work reciprocally and comprises both the subordinate's trust toward his or her supervisor and vice versa (Özyilmaz, 2010). Therefore, organizations that want to build trustworthy relations between their employees should not only consider their performance related outcomes but also focus on the different dimensions of trust and understand how they influence organizational settings (Ozmen, 2018). In other words, employees' trust in their supervisors is normally related to their trust in the management in general (Weibel et al., 2016).

Although work relationships have also become more horizontal and team oriented (Costa et al., 2001), most research focus on vertical trust (e.g. Dirks and Ferrin, 2002; Madjar and Ortiz-Walters, 2009; Guinot and Chiva, 2019). Therefore, this study aims to fill this gap by providing evidence on both the roles of vertical and horizontal trust on organizational climate and team learning.

\subsection{Organizational climate}

Organizational climate is one of the most important variables that have been researched in organizational environment. Organizational climate can be described as a set of measurable properties of the work environment, perceived directly or indirectly by people who live and work in this environment and assumed to influence their motivation and behavior to promote or hinder learning in their work place (Organ et al., 2006; James et al., 2008; Brodbeck, 2003, 2010; Maamari and Messarra, 2012). Organizational climate is related to subjective evaluations, feelings and perception of the actions of organizational members (Gray, 2008).

According to Churchill et al. (1976), organizational climate is the aggregate of the social variables, which create a worker's job environment. For example, Churchill et al. (1976) and Berberoglu (2018) suggested that in order to understand how an employee views organizational climate, it is necessary to consider the employee's perceptions of the work situation (including the characteristics of the organization they work for) and the nature of relationships with other people in the same environment. Glisson and James (2002) argued that an aggregate measure of organizational climate can be determined as an organization level measure of climate only when there is a perceptual agreement among employees. Payne (2000) suggested that organizational climate is how employees view their organization and its purposes. Mullins (2010) believed that organizational climate can defined as "how it feels to work around here". 
Several researchers have considered the relationship on how organizational climate may affect job satisfaction, organizational effectiveness, team learning and individual performance (e.g. Collins and Smith, 2008; Menges et al., 2011; Berberoglu, 2018). Organizational climate has a major influence on quality and quantity of task performed in the organization (Hedman and Valo, 2015). A positive climate gives the possibility that employees are committed to their work and job satisfaction is on a high level. Individuals are satisfied when they have a meaningful and challenging work as well as a chance to learn and grow (Ahmad et al., 2018).

Organizational behaviors, especially the existence of suitable organizational climate, powerful and strong communicative skills in management are the basic factors for the successful team learning. Organizational climate is regarded as a meaningful construct with significant implications in organizational behavior such as team learning. Also in today's organizational environment, expectation is to have high work productivity, so it is not surprising that organizations are in need of employees who will go beyond their call of duty and give job performances that exceed expectations. In this kind of environment ability to create organizational climate, group's behavior becomes more essential (Maamari and Messarra, 2012).

\subsection{Team learning}

Traditionally, project teams are considered to have an established objective with defined life span with a beginning and an end (Larson and Gray, 2015). Turner (1999) and Savelsbergh et al. (2015) identified three levels of a project teams: primary, secondary and tertiary teams. The primary group consists of team who work face to face and who know everyone else in the group, work together for the whole duration of the project and are responsible for execution and completion of the project phases. The secondary group consists of people who contribute to the task of the primary group but not part of it. Secondary teams are specialized teams that are brought in at various project phases to fulfill knowledge gaps with the possibility of enhancing team learning (see Hoegl et al., 2004). Chiocchio et al. (2015) created the term component project team that contains of people or teams who contribute to the project for specialized tasks at specific times. The tertiary group is those affected by the work of the project, for example, the external stakeholders. In this study, project team members refer to the primary group. Project team composition is not static, and project managers are likely to play an integrative role to manage the variation in team composition arising from the withdrawals and entry of project participants during the life cycle of a project (see Eskerod and Blichfeldt, 2005; Chiocchio et al., 2015). From the literature, two aspects of team learning have been identified, consisting of the process of learning (e.g. Edmondson, 2002; Gibson and Vermuelen, 2003; Savelsbergh et al., 2015) and its outcome (Kasl et al., 1997). The process of team learning considers the acquisition of new and common knowledge as an output of team interactions or change and improvement by regulatory and reflexive processes of the team (Widmann and Mulder, 2018). The second aspect examines the team learning processes that generate team-learning outcomes, such as adaptations, improvements, performance and effectiveness (Decuyper et al., 2010). Also, the project team members can be exposed to many different influences that can hinder or enhance teams to learn effectively. Similarly, normally well-structured teams can monitor and address mistakes better than others and can understand who knows what and who is responsible for what (Widmann and Mulder, 2018). Project team members are usually combined efforts of variety of experts from different functional units where knowledge are shared and learned. Continuous learning in terms of both project content and interpersonal dynamics is key driver of the team's ability to remain flexible and adaptive (Savelsbergh et al., 2015). Projects are characterized by complexity and uniqueness, employees ' need to work and learn together and cooperate with others to develop novel, innovative solutions in the organization (Widmann and Mulder, 2018). Team learning
The role of organizational climate

1429 
IJMPB

14,7

\section{0}

is important for all teams to learn how to work together effectively and for organizations to manage their continuously changing environment. Team learning is all about knowledge acquisition, participation and creation (Decuyper et al., 2010). Project team members (PTM) learn when members engage in trial and error and joint problem-solving (Edmondson, 2002). Through this process, a PTM improves its effectiveness by increasing the processing, not the amount, of information (De Dreu, 2007).

\subsection{Trust and team learning}

Trust is an essential component of relationships in organizations because it enables cooperative behavior (Blomqvist, 2002). Trust is a precondition for exchanging behavior (Buvik and Tvedt, 2017) that can lead to effective collaborations that promote information sharing and continuous learning. Projects are unique and temporary requiring cooperation and communication among team members initiated by trust. Trust between members is either affect based or knowledge based. Affect based can be described as "trust at first" which is necessary for team members meeting for the first time carry out a project. On the other hand, knowledge-based trust is built steadily on ongoing relations between the parties over time (Diallo and Thuiller, 2005). Team learning can be evaluated by continuous improvement, increased productivity and customer satisfaction (Smith et al., 2001). Costa (2003) and Dirk (2000) suggest that trust in teams increases the ability of team members to work together with high level of trust leading to improved team performance and high commitment. Trust promotes openness and mutual support and communication and may lead to increased creativity and team learning (Barker and Camarata, 1998). Trust keeps teams together, and team stability is very crucial in creating an innovative and learning environment. Cooperation desired for team learning is continuous and can only be achieved if trust becomes the primary value of the team culture (Edmondson, 2002; Shagholi et al., 2010). Dirks and Ferrin (2002) found that employees' trust in supervisors can create open communication and exploration of new ideas that leads to team learning. Tan and Tan (2000) confirm significant relationship between supervisor trust and innovative behaviors. Similarly, if a team member trusts his/her colleague's ability to perform well, this would encourage the team to support one another and create an atmosphere of psychological safety which can create an environment of creating new ideas and problem-solving. This leads to the following hypothesis:

H1a. There is a positive association between trust among PTM and their supervisors (vertical trust) and team learning

H1b. There is a positive association between trust among PTM members (horizontal trust) and team learning

\subsection{Trust and organizational climate}

The climate of trust has positive expectations regarding the motives, intentions and prospective actions of others (Fainshmidt and Frazier, 2017). Researchers (e.g. Lorenz, 1988; Wathne and Heidi, 2000) mention that increase in trust reduces social complexity in organizations and supports organizational adaptability that improves organizational climate. For example, trust is necessary for cooperation and promotes confidence that allows autonomous but interdependent group members to work together and achieve common goals harmoniously (Ring and Van der Ven, 1992; Diallo and Thuiller, 2005). Trust can enhance team members' willingness to interact with each other and promote a cooperative climate. When employees observe a cooperative atmosphere, they are likely to create interactive relationships with other project team member (Chen and Huang, 2007). Trust strengthens cooperation, reduces conflicts and improves organization climate (Tschannen-Moran and Hoy, 2000; 
Bryk and Schneider, 2002). Positive conflict can create innovation and are often encouraged. When conflict arises among team members, horizontal trust can prevent the conflict from becoming a negative conflict. The lack of trust in teams may lead team members to feel attacked while exchanging ideas (Peterson and Behfar, 2003). The climate for trust also motivates employees to contribute new ways and engage in change-orientated behaviors (Fainshmidt and Frazier, 2017). Increasing trust affects the employees' enterprising behaviors (e.g. creativity, risk-taking behavior and assertiveness). Supervisor trust promotes also the employees' organizational citizenship behavior, allows employees to focus on productive activities and increases the organizational citizenship behaviors (Ozmen, 2018). Managers must demonstrate a feeling of confidence and support for the employees and this could promote favorable organizational climate for free and open discussion (Gilbert and Li-Ping Tan, 1998). Researchers (e.g. Whitener et al., 1998) have found that satisfied managers are those who enjoy both high trust and confidence from their superior. When employees feel that they have confidence from their superior, they sense they are important to the project, and would be more dedicated and be willing to share their knowledge and openly express their views without fear of criticism. This can create a sense of belonging, enables management and employees to discuss things through and may lead to improved organizational climate. Ozyilmaz (2010) observes that there is a possibility that even if PTM do not fully trust their supervisors, they may be willing to stay because they trust their coworkers. Trust in coworkers can lead to increase cooperation and reduce conflicts, which improves organizational climate. This leads to the following hypothesis:

$H 2 a$. The higher the vertical trust, the more favorable the organization climate.

$H 2 b$. The higher the horizontal trust, the more favorable the organization climate

\subsection{Organizational climate and team learning}

Favorable organizational climate provides the environment for team learning. The environment for team learning is characterized by high levels of support and challenge, and sharing new ideas toward a shared innovative vision (Bock et al., 2005). The communication exhibited through trust and favorable organizational climate encourages individuals/team members to support and contribute to innovative ideas that require cooperation and learning new ways of doing things (Barker and Camarata, 1998). A favorable organizational climate is a key driver influencing team learning (Heller et al., 2014). Team learning is also important for teams to learn how to work effectively together and for organizations to manage their continuously changing environment. A climate for team learning is characterized by support and formal and information communication among the team members. A favorable climate ensures the free flow of information and knowledge sharing (Hinds and Pfeffer, 2003), and tolerant of deviant views and failure (Leonard and Sensiper, 1998). A favorable climate is required for team learning behaviors such as experimenting, sharing mistakes and exploring new situations (Edmondson, 1999). In a favorable climate, people listen to each other, ideas are encouraged and new initiative are often created (Ekvall, 1996). This leads to the following hypothesis.

H3. Favorable organizational climate is positively related to team learning.

Mediation is a relationship such that an independent variable affects a mediating variable, which then affects a dependent variable (Preacher et al., 2007). Hypothesis 1 suggests that trust affect team learning. Hypothesis 2 proposes that trust affects organizational climate, and Hypothesis 3 suggest that organizational climate is related to team learning. This means that the organizational climate plays a mediating role in the relationship between the trust and the team learning. (see Figure 1 for the research model). This prediction is emphasized in the following hypothesis:
The role of organizational climate 
IJMPB

14,7
H4. There is a positive indirect relationship between trust and team learning through emphasis on organizational climate.

\section{Research design}

Data were obtained from a Finnish company that is a global leader in smart technologies and complete lifecycle solutions for the marine and energy markets. By emphasizing sustainable innovation, total efficiency and data analytics, the company maximizes the environmental and economic performance of the vessels and power plants of its customers. The company operates in over 70 countries with approximately 18,000 employees.

\subsection{Data collection}

To establish content validity, a review of existing theories and measures suggested that the measurement of trust, organizational climate and team learning could be reliably achieved through the adoption of measures modified from the existing literature. In addition, the survey was pretested. In the pretest phase, inputs were received from the director of research development and engineering and a team of three project managers. They were asked to review the survey and to comment on the language clarity of each question as well as the overall format of the instrument. The pilot test showed that the instrument contained no ambiguities and its length was reasonable. After that, the pretest survey was sent to the target audience of 110 PTM from the organization globally. After given survey submission period of two weeks, responses from 86 individuals were received, generating a response rate of $78 \%$. To examine for response bias, the responses from first $20 \%$ of returns and those from the last 20\% were compared, to test if responses differed between the two groups. Levels of significance were determined for each item using $t$-tests. No differences were identified, providing some support for the absence of a nonresponse bias. On the average, the respondents had worked in the company for 14.6 years and are from six different countries (Finland, Italy, Netherlands, Norway, Spain and China). The sample consisted of 72 men and 13 women.

\subsection{Measurement of construct}

3.2.1 Trust. The measurement items regarding trust were taken from Tyler (2003) and Dietz and Den Hartog (2006). PTM asked how they perceived trust in connection to their supervisors (vertical) and their coworkers that is among PTM (horizontal). The items were: (1) the directors and managers consider my view; (2) the director and managers tries to take my needs into account; (3) the directors and manager try hard to do the right things by me; (4) the directors and managers care about my concern; (5) my views are considered when decisions are made; (6) I trust that my colleagues place the organization's interest above their own; (7) I trust that my colleagues would keep their promises; (8) I trust that my colleagues express

Figure 1.

Research model

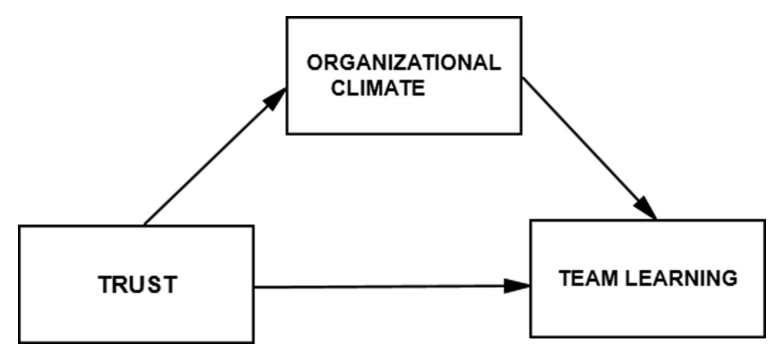


their true feelings about issues; (9) I trust that my colleagues can contribute to the success of the organization; (10) I trust that my colleagues take care about the future of the organization; (11) I trust that my colleagues would acknowledge their mistakes; (12) I trust that my colleagues can be relied upon and (13) In my organization, my colleagues tell the truth if even it is unpleasant.

3.2.2 Organizational climate. Measurement for organizational climate was adopted from Fainshmidt and Frazier (2017) and Maamari and Messarra (2012). Respondents (PTM) were asked to report on the extent to which PTM perceived the organizational climate; (1) there is a very high level of cooperation throughout this organization; (2) friendly atmosphere prevails among the people in this organization; (3) if someone in this organization makes a promise others within the organization will almost always trust that the person will do his or her best to keep the promise; (4) directors and managers in this organization respect their subordinates to make good decisions and (5) in this organization, directors and managers have a great deal of respect for subordinates. The Cronbach alpha of the five-item scale was 0.84 .

3.2.3 Team learning. The measurement of team learning comes from Hedman (2016). Respondents were asked to indicate the degree of emphasis they placed on the measures on a five-point Likert type scale, anchored on $1=$ Strongly disagree to $5=$ Strongly agree. The items were: (1) we discuss the different future organization scenarios openly; (2) we can successfully put our strategies into action; (3) everyone in the team focuses on achieving the shared vision and objectives set by the team; (4) everyone in the team participates actively in decision-making conversations; (5) leadership is always a shared effort; (6) we discuss and evaluate our objectives assumptions, working methods and processes openly and (7) if a team member discovers a problem, he or she will talk about it with other team member. The Cronbach alpha for this scale was 0.75 .

\subsection{Assessment of reliability and validity}

We used both convergent and discriminant validity to assess the valid of the measurement variables. The convergent validity refers to the state when items measure their intended construct, and no other construct, whereas the discriminant validity is confirmed when the construct as a whole differs from the other constructs (Straub, 1989). The convergent validity is assessed by the factor analysis of measurement variables. We used principal component analysis with varimax rotation to determine if all items measuring the TRUST construct together or not. Two factors with eigenvalues greater than unity emerged from the principal component analysis, with solutions retaining $54 \%$ of the total variance. The results of the factor analysis are presented in Table 1 . Factor one relates to emphasizing vertical trust. The second factor emphasizes horizontal trust. The result of the factor analysis is consistent with the literature. The factor analysis showed that both organizational climate and team learning exhibited one dimension (see Tables 2 and 3).

Table 4 presents the descriptive statistics of the variables. Reliability was assessed in two ways: (1) internal consistency (Cronbach alpha) and (2) average variance extraction (AVE). Referring to Table 5 , internal consistency substantially exceeded the generally agreed upon lower limit of 0.60 (Nunnally and Bernstein, 1994). Cronbach's alpha ranged between 0.75 and 0.85. As shown in Table 5, AVE range from 0.40 to 0.61 . Both Cronbach alpha and AVE calculations confirmed the measures of reliability (Fraering and Minor, 2006; Hair et al., 2012)

\section{Correlation analysis and testing of hypotheses}

To test our mediation model, we employed correlational analysis and structural equation modeling. Table 6 presents the results of the correlation matrix. 


\section{IJMPB 14,7}

The directors and managers consider my view 0.838

The director and managers tries to make my needs into account

0.823

The directors and manager try hard to do the right things by me

0.802

The directors and managers care about my concern

0.688

My views are considered when decisions are made

0.680

I trust that my colleagues can be relied upon

I trust that my colleagues would keep their promises

I trust that my colleagues can contribute to the success of the organization

I trust that my colleagues would acknowledge their mistakes

I trust that my colleagues take care about the future of the organization

I trust that my colleagues place the organization's interest above their own

I trust that my colleagues express their true feelings about issues

0.539

Factor analysis of trust In my organization, my colleagues tell the truth if even it is unpleasant
Table 2.

Factor analysis of organizational climate

\section{Questions}

In this organization, directors and managers have a great deal of respect for subordinates

There is a very high level of cooperation throughout this organization

Directors and managers in this organization respect their subordinates to make good decisions $\quad 0.813$

If someone in this organization makes a promise other within the organization will almost always trust $\quad 0.704$

that the person will do his or her best to keep the promise

Friendly atmosphere prevails among the people in this organization

Questions

We discuss and evaluate our objectives assumptions working methods and processes openly $\quad 0.744$

$\begin{array}{ll}\text { Everyone in the team participates actively in decision-making conversations } & 0.707\end{array}$

$\begin{array}{ll}\text { We discuss the different future organization scenarios openly } & 0.684\end{array}$

Everyone in the team focuses on achieving the shared vision and objectives set by the team $\quad 0.643$

Table 3. If a team member discovers a problem, he or she will talk about it with other team member 0.618

Factor analysis of team Leadership is always a shared effort 0.564

learning We can successfully put our strategies into action 0.512

\begin{tabular}{lcccc}
\hline & $N$ & Mean & Std. Deviation & $Z$ value for skewness \\
\hline Horizontal trust (HT) & 86 & 3.73 & 0.51 & -1.20 \\
Vertical trust (VT) & 86 & 3.56 & 0.62 & -1.24 \\
Organizational Climate (OC) & 86 & 3.49 & 0.65 & -1.75 \\
Team learning (TL) & 86 & 3.44 & 0.54 & 2.45 \\
\hline
\end{tabular}

Table 4.

Descriptive statistics

\begin{tabular}{llcccc}
\hline & \multicolumn{1}{c}{} & & & \\
\cline { 2 - 6 } & Variable & No of. Items & Cronbach alpha & AVE & Composite reliability \\
\cline { 2 - 6 } & Horizontal trust (HTRUST) & 8 & 0.79 & 0.40 & 0.82 \\
Table 5. & Vertical trust (VTRUST) & 5 & 0.85 & 0.50 & 0.87 \\
Reliability measures of & Organizational climate (OC) & 5 & 0.84 & 0.61 & 0.88 \\
construct & Team learning (TLEAN) & 7 & 0.75 & 0.41 & 0.82 \\
\hline
\end{tabular}


The first hypothesis H1a suggested a positive relationship between vertical trust (VTRUST) and team learning (TLEAN). Relationship was supported $(r=0.44, p<0.01)$. The second hypothesis H1b suggested a positive relationship between horizontal trust (HTRUST) and TLEAN. The hypothesis was confirmed $(r=0.57, p<0.01)$. This shows that horizontal trust has greater effect on team learning than vertical trust. Hypothesis H2a suggested a positive relationship between vertical trust (VT) and organizational climate (OC) was supported $(r=0.67, p<0.01)$. The results of hypothesis $2 \mathrm{~b}$ describing the relationship between HTRUST and OC was supported $(r=0.69, p<0.01)$. The third hypothesis H3 was between OC and team TLEAN. H3 suggested a positive relationship and linkage between OC and TL. The relationship was confirmed $(r=0.70, p<0.01)$, suggesting the mediating role of organizational climate. Multicollinearity was performed, and results indicate that it was not a problem for our analysis. Variance inflation index was less than 2 which meets the criteria recommended by Hair et al. (2012).

For hypothesis 4, AMOS 23 was used to test the mediation effect of organizational climate on the relationship between trust and team learning (see Figure 1). In order to provide additional insight, the mediation was performed with the two variants of trust (vertical and horizontal trust). To further test our hypothesis 4, a path analysis technique using AMOS was used to evaluate the model in Figure 2. We relied on the unstandardized parameter estimates for our theoretical model to further test the hypothesis and indirect effects.

Figure 2 above shows the unstandardized estimates for the relationships among trust, organizational climate and team learning. The hypothesized model appeared to fit the data. Maximum likelihood estimation was used because the research data were normally distributed. The CFI was 0.99 , TLI was 0.98 and RMSEA was 0.06 . We did not conduct post hoc modifications because of the good fit of the data to the model data (chi-square $=3.1$, $\mathrm{df}=2, p=0.22$ ). Table 7 shows that horizontal trust is positively related to organizational climate (regression coefficient $=0.58, p=0.00$ ) confirming earlier results. Furthermore, vertical trust is positively related to organizational climate (regression coefficient $=0.43$, $p<0.01$ ). Confirming earlier analysis above, organizational climate significantly affecting team learning positively with direct and significant relationship (regression

\begin{tabular}{lllll}
\hline & 1 & 2 & \multicolumn{1}{c}{3} & 4 \\
\hline 1. Horizontal trust & 1.00 & $0.55^{* *}$ & $0.69^{* *}$ & $0.57^{* *}$ \\
2. Vertical trust & & 1.00 & $0.67^{* *}$ & $0.44^{* *}$ \\
3. Organizational climate & & & 1.00 & $0.70^{* *}$ \\
4. Team learning & & & & 1.00
\end{tabular}

Note(s): ** Correlation is significant at the 0.01 level
The role of organizational climate

1435

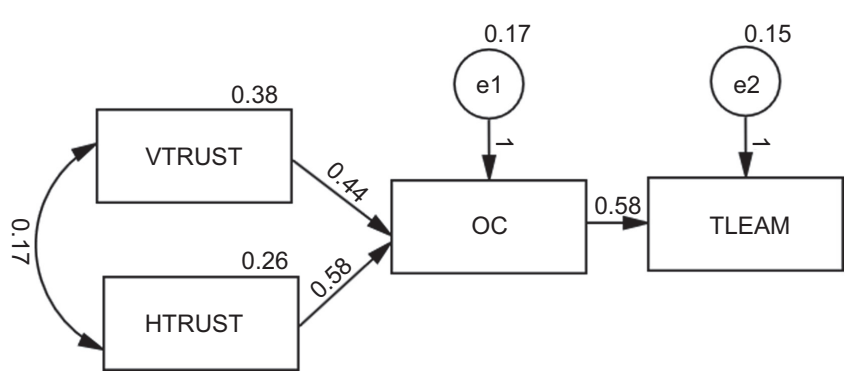

Figure 2.

Structural equation modeling model (unstandardized estimates) 
IJMPB

14,7

coefficient $=0.58, p=0.00$ ). Our results show that horizontal trust plays more role in predicting a favorable organizational climate than vertical trust.

Table 8 presents the standard regression weight for the research model. The path analysis shows that trust accounted for $60 \%$ of the variance in organizational climate, with a standardized path coefficient of 0.46 for horizontal trust (HT) and 0.42 for vertical trust (VT). The path coefficient between the emphasis on organizational climate and team learning is 0.69 , and accounted for $49 \%$ of the variance in team learning.

We tested the significance of the indirect effects by using the bootstrap method, for overviews of testing indirect effects in mediation (MacKinnon et al., 2004; Shrout and Bolger, 2002). We used AMOS with 5,000 bootstrap samples to obtain the lower and upper limits of a $95 \%$ confidence interval for the population indirect effect of trust on team learning through organizational climate. The total indirect effect of vertical trust on team learning is 0.25 and horizontal trust on team learning is 0.34 . The resulting interval was $\mathrm{CI}_{0.95}:\{0.20 ; 0.53\}$ for horizontal trust and $\mathrm{CI}_{0.95}:\{0.16 ; 0.37\}$ for vertical trust. The lower limits $(0.20)$ and $(0.16)$, respectively, are above zero. Thus, the confidence interval and supports $\mathrm{H} 4$ that states trust influences team learning indirectly through favorable organizational climate.

\section{Discussions and conclusions}

The objective of this study is to examine the relationship between trust, organizational climate and team learning. Our findings show that trust promotes team learning through the mediating effect of organizational climate. In addition, the present study provides information on the effects of vertical and horizontal trust on organizational climate and team learning. Our results show that horizontal trust has greater effect on both organizational climate and team learning compared to vertical trust. In general, when team members trust each other, they are likely to interact and create a cooperative and favorable climate. When PTM perceive a favorable climate, they can freely suggest ideas and propose new initiatives. PTM are encouraged to declare their ideas and initiatives because they trust each, exchange information and knowledge which promotes team learning (Ekvall, 1996; Chen and Huang, 2007)

Our study provides theoretical implications. First, this study contributes to the growing body of work on predictors of team learning. Earlier research explored the benefits of team learning (Edmondson, 1999) and important predictors of team learning such as group behavior (Widmann and Mulder, 2018), team leadership (Savelsbergh et al., 2015) and organizational climate, (Chen and Huang, 2007). Although trust has been mentioned to play an important role in team learning (e.g. Chow and Chan, 2008; Dirks and Ferrin, 2001), no research has been

Table 7.

Regression weight of variables in SEM Model (unstandardized estimates)

\begin{tabular}{lcc}
\hline & Estimate & $P$ value \\
\hline VTrust-Organizational climate & 0.43 & 0.00 \\
HTrust-Organizational climate & 0.58 & 0.00 \\
OClimate-TLearning & 0.59 & 0.00 \\
\hline
\end{tabular}

Table 8.

Standardized Regression weight of variables in SEM Model

\begin{tabular}{lcc}
\hline & Estimate & $P$ value \\
\hline VTrust-Organizational climate & 0.42 & 0.00 \\
HTrust-Organizational climate & 0.46 & 0.00 \\
OClimate-TLearning & 0.69 & 0.00 \\
\hline
\end{tabular}


studied on how both vertical and horizontal trust, and organizational climate influence team learning. The study extends this focus by exploring how PTM perceive trust to their supervisors and their coworkers and its relationship with organizational climate and team learning. The empirical results of the current study add to our understanding of trust by examining its relationship with organization climate. Our study explored simultaneously the role of horizontal trust and vertical trust in creating a favorable organizational climate to enhance team learning. Previous researches have been less clear about how both types of trust simultaneously influence organizational climate and team learning. The finding of this study shows that horizontal trust may create a more favorable organizational climate compared to vertical trust. Our results are consistent with the findings of Ozyilmaz (2010) that there is a possibility that even if PTM do not fully trust their supervisors, they may be willing to stay because they trust their coworkers (vertical trust).

Second, our results also indicate the importance of horizontal trust. When PTM perceive that trust exists between themselves and their supervisors, they are more likely to work collaboratively to enhance favorably organizational climate (Kassing, 2000). For PTM to work collaboratively, PTM should feel a sense of trust and support that allows them to communicate openly about difficult issues that might not be in harmony of organizational interest (Payne, 2014). The fact that horizontal trust has more influence on organizational climate compared to vertical impact shows the degree of importance of coworker climate in team learning.

Third, we hypothesized that organizational climate would mediate the effect of trust on team learning. Our results support previous research (e.g. Ekvall, 1996; Pörzse et al., 2012), who suggested the potential mediating effect organizational climate as a key driver in promoting team learning and innovations in organizations.

From a practical point, our study shows the importance of considering both types of trust when dealing with organizational climate and team learning. Employees who trust their coworkers and supervisors may feel more satisfied at work and are likely to contribute to favorable organizational climate (Dirks and Ferrin, 2001; Carmeli et al., 2011). Organizations should also pay more attention to increase trust at the work place especially coworkers that may contribute to a favorable organizational climate which is vital for team learning.

Our study employed the survey method, and is not without limitations. The first limitation concerns our sample, which was selected from one global company. Further research using a large sample size is needed to determine the robustness of our results. Generalizing our results to other companies should be done cautiously. Second, our data were all collected at a single point in time. Consequently, we cannot unambiguously infer causality. To attempt to do so, it would be useful to investigate our model in the context of organizational and development change. Future research may explore how different constructs such as the environmental and task uncertainty affect trust and team learning.

\section{References}

Ahmad, K.Z.B., Jasimuddin, S.M. and Kee, W.L. (2018), "Organizational climate and job satisfaction: do employees'personalities matter?”, Management Decision, Vol. 56, pp. 421-440.

Barker, R.T. and Camarata, M.R. (1998), "The role of communication in creating and maintaining a learning organization: preconditions, indicators, and disciplines", The Journal of Business Communication, Vol. 35 No. 4, pp. 443-467.

Barnett, M., Anderson, J., Houle, M., Higginbotham, T. and Gatling, A. (2010), “The process of trust building between university researchers and urban school Personnel”, Urban Education, Vol. 45 No. 5 , pp. 630-660.

Berberoglu, A. (2018), "Impact of organizational climate on organizational commitment and perceived organizational performance: empirical evidence from public hospitals", BMC Health Services Research, Vol. 18, p. 399.
The role of organizational climate 
IJMPB 14,7

Birkinshaw, J. and Mol, M.J. (2006), "How management innovation happens", Sloan Management Review, Vol. 47 No. 4, pp. 81-88.

Blomqvist, K. (2002), Partnering in the Dynamic Environment: The Role of Trust in Asymmetric Technology Partnership Formation, Doctoral dissertation, Lappeenranta University of Technology, Acta Universitatis Lappeenrantaensis, Vol. 122.

Bock, G., Zmud, R., Kim, Y. and Lee, J. (2005), "Behavioral intention formation in knowledge sharing: examining the roles of extrinsic motivators, social-psychological forces, and organizational climate”, MIS Quarterly, Vol. 29 No. 1, pp. 87-111, doi: 10.2307/25148669.

Brodbeck, F.C. (2003), Team Climate for Learning in Higher Education, Aston Network (Summer), Birmingham, pp. 4-5.

Brodbeck, F.C., Guillaume, Y.R.F. and Winkler, M. (2010), Team Climate for Individual Learning, Unpublished paper.

Bryk, A. and Schneider, B. (2002), Trust in Schools: A Core Resource for Improvement, Russell Sage Foundation, New York, NY.

Buvik, M.P. and Tvedt, S.D. (2017), "The influence of project commitment and team commitment on the relationship between trust and knowledge sharing in project teams", Project Management Journal, Vol. 48 No. 2, pp. 5-21.

Carmeli, A., Tishler, A. and Edmonson, A.C. (2011), "CEO relationship leadership and strategic decision in top management teams: the role of team trust and learning from failure", Strategic Organization, Vol. 10 No. 1, pp. 31-54.

Chen, C.J. and Huang, J.W. (2007), "How organizational climate and structure affect knowledge management-the social interaction perspective", International Journal of Information Management, Vol. 27 No. 2, pp. 104-118.

Chiocchio, F., Forgues, D., Paradis, D. and Iordanova, I. (2011), "Teamwork in integrated design projects: understanding the effects of trust, conflict, and collaboration on performance", Project Management Journal, Vol. 42 No. 6, pp. 78-91.

Chiocchio, F., Kelloway, E.K. and Hobbs, B. (2015), The Psychology and Management of Project Teams, Oxford University Press, New York.

Chow, W.S. and Chan, L.S. (2008), "Social network, social trust and shared goals in organizational knowledge sharing", Information and Management, Vol. 45 No. 7, pp. 458-465.

Churchill, G.A., Ford, N.M. and Walker, O.C. (1976), "Organizational climate and job satisfaction in the sales force”, Journal of Marketing Research, Vol. 13, pp. 323-32.

Clark, M.C. and Payne, R.L. (1997), "The nature and structure of workers' trust in management", Journal of Organizational Behavior, Vol. 18, pp. 205-224.

Collins, J. and Smith, K.G. (2008), "Knowledge exchange and combination: the role of human resource practices in the performance of high-technology firms", Academy of Management Journal, Vol. 49 No. 2006, pp. 44-60.

Colquitt, J.A., Scott, B.A. and Lepine, J.A. (2007), "Trust, Trustworthiness and Trust propensity: a metal Analytic Test of their unique relationships with Risk Taking and job performance", Journal of Applied Psychology, Vol. 92, pp. 909-922.

Costa, A.C. (2003), "Work team trust and effectiveness", Journal of Personnel Review, Vol. 32 No. 5, pp. $605-622$.

Costa, A.C. and Anderson, N. (2011), "Measuring trust in teams: development and validation of a multifaceted measure of formative and reflective indicators of team trust", European Journal of Work and Organizational Psychology, Vol. 20 No. 1, pp. 119-154.

Costa, A.C., Roe, R.A. and Taillieu, T. (2001), "Trust within teams: the relation with performance effectiveness", European Journal of Work and Organizational Psychology, Vol. 10 No. 3, pp. 225-244.

De Dreu, C.K.W. (2007), "Cooperative outcome interdependence, task reflexivity, and team effectiveness: a motivated information processing perspective", Journal of Applied Psychology, Vol. 92, pp. 628-38. 
Decuyper, S., Dochy, F. and Van den Bossche, P. (2010), "Grasping the dynamic complexity of team learning: an integrative model for effective team learning in organization", Educational Research Review, Vol. 5 No. 2, pp. 111-133.

Diallo, A. and Thuillier, D. (2005), "The success of international development projects, trust and communication: an African perspective", International Journal of Project Management, Vol. 23 No. 3, pp. 237-252.

Dietz, G. and Den Hartog, D.N. (2006), "Measuring trust inside organisations", Personnel Review, Vol. 35 No. 5, pp. 557-588.

The role of organizational climate

Dirks, K.T. and Ferrin, D.L. (2001), "The role of trust in organizational settings", Organization Science, Vol. 12 No. 4, pp. 450-467.

Dirks, K.T. and Ferrin, D.L. (2002), "Trust in leadership: meta-analytic findings and implications for research and practice", Journal of Applied Psychology, Vol. 87, pp. 611-628.

Dirks, K.T. (2000), "Trust in leadership and team performance: evidence from NCAA basketball", Journal of Applied Psychology, Vol. 85 No. 6, pp. 1004-1012.

Edmondson, A.C., Dillon, J.R. and Roloff, K.S. (2007), "Three perspectives on team learning: outcome improvement, task mastery, and group process", The Academy of Management Annals, Vol. 1, pp. 1-57.

Edmondson, A. (1999), "Psychological safety and learning behavior in work teams", Administration Science Quarterly, Vol. 44, pp. 350-83.

Edmondson, A. (2002), "The local and variegated nature of learning in organizations", Organization Science, Vol. 13 No. 2, pp. 128-146.

Ekvall, G. (1996), "Organizational climate for creativity and innovation”, European Journal of Work and Organizational Psychology, Vol. 5 No. 1, pp. 105-23.

Eskerod, P. and Blichfeldt, B.S. (2005), "Managing team entrees and withdrawals during the project life cycle", International Journal of Project Management, Vol. 23 No. 7, pp. 495-503.

Fainshmidt, S. and Frazier, M.L. (2017), "What facilitates dynamic capabilities? The role of organizational climate for trust”, Long Range Planning, Vol. 50 No. 5, pp. 550-566, doi: 10.1016/j. lrp.2016.05.005.

Fraering, M.A. and Minor, M.S. (2006), "The sense of community: an exploratory study of US consumers of financial services", International Journal of Bank Marketing, Vol. 24 No. 5, pp. 284-306.

Gevers, J.M.P., van Eerde, Wendelien and Rutte, C.G. (2009), "Team self-regulation and meeting deadlines in project teams: antecedents and effects of temporal consensus", European Journal of Work and Organizational Psychology, Vol. 18 No. 3, pp. 295-321.

Gibson, C.B. and Vermeulen, F. (2003), "A healthy divide: subgroups as a stimulus for team learning behaviour”, Administrative Science Quarterly, Vol. 48, pp. 202-239.

Gilbert, J. and Li-Ping Tang, T. (1998), “An examination of organizational trust antecedents”, Public Personnel Management, Vol. 27 No. 3, pp. 321-338.

Glisson, C. and James, L.R. (2002), "The cross-level effects of culture and climate in human service teams", Journal of Organizational Behavior, Vol. 23 No. 6, pp. 767-794.

Gray, R. (2008), "How it feels to work here: improving organisational climate", The International Journal of Knowledge, Culture, and Change Management: Annual Review, Vol. 8 No. 9, pp. 85-92, doi: 10.18848/1447-9524.

Guinot, J. and Chiva, R. (2019), "Vertical trust within organizations and performance: a systematic review”, Human Resource Development Review, Vol. 18 No. 2, pp. 196-227.

Hair, J.F., Black, W.C., Babin, B.J. and Anderson, R.E. (2012), Multivariate Data Analysis, 7th ed., Pearson Education, Upper Saddle River, NJ.

Hedman, E. and Valo, M. (2015), "Communication challenges facing management teams”, Leadership and Organization Development Journal, Vol. 36 No. 8, pp. 1012-1024. 
IJMPB 14,7

Hedman, E. (2016), "Leadership Team Tool for better meaning making: developing leadership team communication and reflexivity", Journal of Management Development, Vol. 35 No. 5, pp. 592-605.

Heller, B., Berger, R. and Brodbeck, R. (2014), "Does an adequate team climate for learning predict team effectiveness and innovation potential? A psychometric validation of the team climate questionnaire for learning in an organizational context”, Procedia-Social and Behavioral Sciences, Vol. 114, pp. 543-550.

Henderson, L.S., Stackman, R.W. and Lindekilde, R. (2016), "The centrality of communication norm alignment, role clarity, and trust in global project teams", International Journal of Project Management, Vol. 34 No. 8, pp. 1717-1730.

Hinds, P.J. and Pfeffer, J. (2003), "Why organizations don't "know what they know": cognitive and motivational factors affecting the transfer of expertise", Sharing Expertise: Beyond Knowledge Management, MIT Press, Cambridge, Massachusetts, pp. 3-26.

Hoegl, M., Weinkauf, K. and Gemuenden, H.G. (2004), "Interteam coordination, project commitment, and teamwork in multiteam R\&D projects: a longitudinal study", Organization Science, Vol. 15 No. 1, pp. 38-55.

Huang, C., Huang, J. and Chang, Y. (2017), "Team goal orientation composition, team efficacy, and team performance: the separate roles of team leader and members", Journal of Management and Organization, Vol. 25 No. 6, pp. 825-843, doi: 10.1017/jmo.2016.62.

Ilgen, D.R., Hollenbeck, J.R., Johnson, M. and Jundt, D. (2005), "Teams in organizations: from InputProcess-Output models to IMOI models", Annual Reviews in Psychology, Vol. 56, pp. 517-543.

Imam, H. and Zaheer, M.K. (2021), "Shared leadership and project success: the roles of knowledge sharing, cohesion and trust in the team", International Journal of Project Management. doi: 10.1016/j. ijproman.2021.02.006.

Jahansoozi, J. (2006), "Organization-stakeholder relationships: exploring trust and transparency", Journal of Management Development, Vol. 25 No. 10, pp. 942-955.

James, L.R., Choi, C.C., Ko, C.-H.E., McNeil, P.K., Minton, M.K., Wright, M.A. and Kim, K. (2008), "Organizational and psychological climate: a review of theory and research", European Journal of Work and Organizational Psychology, Vol. 17 No. 1, pp. 5-32, doi: 10.1080/ 13594320701662550.

Kasl, E., Marsick, V. and Dechant, K. (1997), “Teams as learners: a research-based model on team learning", Journal of Applied Behavioral Science, Vol. 33, pp. 227-246.

Kassing, J.W. (2000), "Investigating the relationship between superior-subordinate relationship quality and employee dissent", Communication Research Reports, Vol. 17, pp. 58-70.

Kozlowski, S.W.J. and Bell, B.S. (2008), “Team learning, development, and adaptation”, in Sessa, V.I. and London, M. (Eds), Work Group Learning, Lawrence Erlbaum, Mahwah, NJ, pp. 15-44.

Kozlowski, S.W.J. and Ilgen, D.R. (2006), "Enhancing the effectiveness of work groups and teams", Psychological Science in the Public Interest, Vol. 7 No. 3, pp. 77-124.

Larson, E. and Gray (2015), Project Management: The Managerial Process, 5th ed., Mc-Graw Hill, New York.

Leonard, D. and Sensiper, S. (1998), "The role of tacit knowledge in group innovation", California Management Review, Vol. 40, pp. 112-132.

Lewicki, R.J., Tomlinson, E.C. and Gillespie, N. (2006), "Models of interpersonal trust development: theoretical approaches, empirical evidence, and future directions", Journal of Management, Vol. 32 No. 6, pp. 991-1022.

Lin, H.F. (2007), "Knowledge sharing and firm innovation capability: an empirical study", International Journal of Manpower, Vol. 28, pp. 315-332.

Lorenz, E.H. (1988), "Neither friends nor strangers: informal networks of subcontracting in French industry", in Gambetta, D. (Ed.), Trust: Making and Breaking Cooperative Relations, Blackwell, New York, NY, pp. 194-210. 
Maamari, B.E. and Messarra, L.C. (2012), "An empirical study of the relationship between organizational climate and organizational citizenship behavior", European Journal of Management, Vol. 12 No. 3, pp. 1-12.

MacKinnon, D.P., Lockwood, C.M. and Williams, J. (2004), "Confidence limits for the indirect effect: distribution of product and resampling methods", Multivariate Behavioral Research, Vol. 39, pp. 99-128.

Madjar, N. and Ortiz-Walters, R. (2009), "Trust in supervisors and trust in customers: their independent, relative, and joint effects on employee performance and creativity", Human Performance, Vol. 22, pp. 128-142.

Marks, M.A., Mathieu, J.E. and Zaccaro, S.J. (2001), "A temporally based framework and taxonomy of team processes", Academy of Management Review, Vol. 26, pp. 356-376.

Menges, J., Walter, F., Vogel, B. and Bruch, H. (2011), "Transformational leadership climate: performance linkages, mechanisms, and boundary conditions at the organizational level", Leadership Quarterly, Vol. 22, pp. 893-909.

Mullins, J. (2010), Management and Organisational Behavior Ninth, 9th ed., FT Prentice Hall, Upper Saddle River, New Jersey.

(2008), in Nemiro, J., Beyerlein, M.M., Bradley, L. and Beyerlein, S. (Eds), The Handbook of HighPerformance Virtual Teams: A Toolkit for Collaborating across Boundaries, John Wiley \& Sons.

Nunnally, J.C. and Bernstein, I.H. (1994), Psychometric Theory, McGraw-Hill, New York, NY.

Organ, D.W., Podsakoff, P.M. and MacKenzie, S.B. (2006), Organizational Citizenship Behavior: Its Nature, Antecedents, and Consequences, Sage Publications, Thousand Oaks.

Ozmen, Y.S. (2018), "How employees define organisational trust: analysing employee trust in organisation”, Journal of Global Responsibility, Vol. 9 No. 1, pp. 21-40.

Özyilmaz, Y.D.A. (2010), "Vertical trust in organizations: a review of empirical studies over the last decade", Journal of Social Sciences Institute, Vol. 7 No. 13, pp. 1-28.

Payne, R.L. (2000), "Climate and culture: how close can they get?”, in Ashkanasy, N.M., Wilderom, C.P.M. and Peterson, M.F. (Eds), Handbook of Organizational Culture and Climate, SagePublications, Thousand Oaks, CA, pp. 163-176.

Payne, H. (2014), "Examining the relationship between trust in supervisor-employee relationships and workplace dissent expression”, Communication Research Reports, Vol. 31, pp. 131-140.

Peterson, R.S. and Behfar, K.J. (2003), "The dynamic relationship between performance feedback, trust, and conflict in groups: a longitudinal study", Organizational Behavior and Human Decision Processes, Vol. 92 Nos 1-2, pp. 102-112.

Pinto, J.K., Slevin, D.P. and English, B. (2009), "Trust in projects: an empirical assessment of owner/ contractor relationships", International Journal of Project Management, Vol. 27 No. 6, pp. 638-648.

PMBOK (2013), A Guide to the Project Management Body of Knowledge: Pmbok Guide, Project Management Institute, Newtown Square, Pennsylvania.

Porzse, G., Takacs, S., Csedo, Z., Berta, Z., Sara, Z. and Fejes, J. (2012), "The impact of creative organizational climate on the innovation activity of medical devices manufacturing firms in Hungary”, European Journal of Business Management, Vol. 4 No. 13, pp. 1-11.

Preacher, K.J., Rucker, D.D. and Hayes, A.F. (2007), "Addressing moderated mediation hypotheses: theory, methods, and prescriptions", Multivariate Behavioral Research, Vol. 42 No. 1, pp. 185-227.

Ramírez, H.B., Berger, R. and Brodbeck, F. (2014), "Does an adequate team climate for learning predict team effectiveness and innovation potential? A psychometric validation of the team climate questionnaire for learning in an organizational context”, Procedia - Social and Behavioral Sciences, Vol. 114, pp. 543-550.

Ring, P.S. and Van de Ven, A.H. (1992), "Structuring cooperative relationships between organizations", Strategic Management Journal, Vol. 12, pp. 1483-98.
The role of organizational climate 
IJMPB 14,7

Savelsbergh, C.H., Poell, R. and Van der Heijden, B. (2015), "Does team stability mediate the relationship between leadership and team learning? An empirical study among Dutch project teams", International Journal of Project Management, Vol. 33 No. 2, pp. 406-418.

Schaubroeck, J., Lam, S.S.K. and Peng, A.C. (2011), "Cognition-based and affect-based trust as mediators of leader behaviour influences on team performance", Journal of Applied Psychology, Vol. 96 No. 4, pp. 863-871.

Schneider, B. and Barbera, K. (2013), The Oxford Handbook of Organizational Climate and Culture, Oxford University Press, Cheltenham.

Schneider, B., Bowen, D.E., Ehrhart, M.G. and Holcombe, K.M. (2000), "The climate for . . .", Journal of Applied Behavioral Science, Vol. 18, pp. 257-273.

Shagholi, R., Hussin, S., Siraj, S., Naime, A. and Moayedi, F. (2010), "Value creation trust, decision making and team work in educational environment", Procedia Social and Behvioural Sciences, Vol. 2, pp. 255-259.

Shrout, P.E. and Bolger, N. (2002), "Mediation in experimental and non-experimental studies: new procedures and recommendations", Psychological Methods, Vol. 7, pp. 422-45.

Smith, P.A., Hoy, W.A. and Sweetland, S.R. (2001), "Organizational health of high schools and dimensions of faculty trust”, Journal of School Leadership, Vol. 12, pp. 135-50.

Smyth, H., Gustafsson, M. and Ganskau, E. (2010), "The value of trust in project business", International Journal of Project Management, Vol. 28 No. 2, pp. 117-129, doi: 10.1016/j.ijproman. 2009.11.007.

Soderlund, J., Vaagasar, A. and Anderson, E. (2008), "Relating, reflecting and routinizing: developing project competence in cooperating with clients", International Journal of Project Management, Vol. 26, pp. 517-528.

Straub, D.W. (1989), "Validating instruments in MIS research", MIS Quarterly, Vol. 13 No. 2, pp. 147-66.

Tan, H.H. and Lim, A.K. (2009), "Trust in coworkers and trust in organizations", The Journal of Psychology, Vol. 143 No. 1, pp. 45-66.

Tan, H.H. and Tan, C.S.F. (2000), "Toward the differentiation of trust in supervisor and trust in organization”, Genetic, Social, and General Psychology Monographs, Vol. 126, pp. 241-260.

Tjosvold, D., Hui, C., Ding, D.Z. and Hu, J. (2003), "Conflict values and team relationships: conflict's contribution to team effectiveness and citizenship in China", Journal of Organizational Behavior, Vol. 24 No. 1, pp. 69-88.

Tschannen-Moran, M. and Hoy, W.K. (2000), “A multidisciplinary analysis of the nature, meaning, and measurement of trust", Review of Educational Research, Vol. 70, pp. 547-93.

Turner, J. (1999), The Handbook of Project Based Management, McGraw Hill, London.

Tyler, T.R. (2003), “Trust within organisations”, Personnel Review, Vol. 32 No. 5, pp. 556-568.

Van der Haar, S., Koeslag-Kreunen, M., Euwe, E. and Segers, M. (2017), "Team leader structuring for team effectiveness and team learning in command-and-control teams", Small Group Research, Vol. 48 No. 2, pp. 215-248, doi: 10.1177/1046496417689897.

Wang, J.F.J.F. and Tarn, D.D.C. (2018), "Are two heads better than one? Intellectual capital, learning and knowledge sharing in a dyadic interdisciplinary relationship", Journal of Knowledge Management,Vol. 22 No. 6, pp. 1379-1407.

Wang, X. (2001), "International student paper award winner: dimensions and current status of project management culture", Project Management Journal, Vol. 32 No. 4, pp. 4-17.

Wasko, M. and Faraj, S. (2000), "It is what one does: why people participate and help others in electronic communities of practice", The Journal of Strategic Information Systems, Vol. 9, pp. 155-173.

Wathne, K.H. and Heidi, J.B. (2000), "Opportunism in interfirm relationships: forms, outcomes, and solutions", Journal of Marketing, Vol. 64, pp. 36-51. 
Weibel, A., Den Hartog, D.N., Gillespie, N., Searle, R., Six, F. and Skinner, D. (2016), "How do controls impact employee trust in the employer?", Human Resource Management, Vol. 55, pp. 437-462.

Whitener, E.M., Brodt, S.E. and Korsgaard, W.J.M. (1998), "Managers as initiators of trust: an exchange relationship framework for understanding managerial trustworthy behaviour", Academy of Management, Vol. 23 No. 3, pp. 513-30.

Widmann, A. and Mulder, R.H. (2018), "Team learning behaviours and innovative work behaviour in work teams", European Journal of Innovation Management, Vol. 21 No. 3, pp. 501-520.

Winter, M., Smith, C., Morris, P. and Cicmil, S. (2006), "Directions for future research in project management: the main findings of a UK government-funded research network", International Journal of Project Management, Vol. 24 No. 8, pp. 638-649, doi: 10.1016/j.jproman.2006.08.009.
The role of organizational climate

\section{Corresponding author}

Adebayo Agbejule can be contacted at: ade@vamk.fi

For instructions on how to order reprints of this article, please visit our website: 